\title{
The Charging of Administrative Fee for Customers of Mudharabah Saving Depositors
}

\author{
Danang Wahyu Muhammad, Mega Mustika \\ Faculty of Law, Universitas Muhammadiyah Yogyakarta, Indonesia. \\ E-mail: danangwahyu@umy.ac.id \\ Master of Laws, Universitas Muhammadiyah Yogyakarta, Indonesia. \\ E-mail: nirfhamustika87@gmail.com
}

\section{ARTICLE INFO \\ Keywords: \\ Administrative Fee, \\ Shahibul Maal, \\ Mudharabah Saving. \\ How to cite: \\ Muhammad D.W., \\ Mustika M. The \\ Charging of \\ Administrative Fee for \\ Customers of \\ Mudharabah Saving \\ Depositors. MEDIA \\ HUKUM, +62 274 \\ 387656 (Ext. 220) \\ Article History \\ Received: $13 / 12 / 2018$ \\ Reviewed: 10/05/2019 \\ Revised: \\ Accepted: 01/07/2019}

\begin{abstract}
One of the saving products in Islamic banks is mudharabah. In the practice of mudharabah saving, there are Islamic banks charge an administrative fee and some do not. The research aims to clarify the figh basis of the charge of administrative fees to Shahibul Maal by mudharib in mudharabah saving. This normative research used secondary data consisting of primary, secondary, and tertiary legal materials. It is found that the charge of administrative fee by mudharib to Shahibul Maal on mudharabah saving does not have a clear foundation in figh. Based on the Fatwa of the National Sharia Board (DSN), the operational cost of mudharabah savings is the responsibility of the Mudharib and not the Shahibul Maal, since the Shahibul Maal has provided the fund. Mudharib can charge for the operational cost only if there is an agreement with the Shahibul Maal.
\end{abstract}

DOI: 10.18196/jmh.20190126

Copyright (C) 2019 MEDIA HUKUM. All rights reserved.

Bank Syariah adalah bank yang dalam operasionalnya tidak menggunakan mekanisme bunga, oleh karena itu disebut bank tanpa bunga. Tidak dikenalnya mekanisme bunga pada bank syariah dikarenakan bunga dianggap riba menurut ketentuan yang ada dalam al-Quran dan Hadits Nabi SAW. Konsekuensinya, dalam pengembangan produk-produk pada bank syariah dan operasionalnya harus selalu berlandaskan pada Al-Quran dan Hadist Nabi SAW. ${ }^{1}$ Namun demikian, sama dengan bank konvensional, fungsi utama dari bank syariah adalah menghimpun dana dari masyarakat dan menyalurkan dana kepada masyarakat, sebagaimana ditentukan dalam UU Nomor 21 Tahun 2008 tentang Perbankan Syariah (selanjutnya ditulis UU Perbankan Syariah).

${ }^{1}$ Muhammmad. (2005), Konstruksi Mudharabah dalam Bisnis Syariah, Yogyakarta: BPFE-Yogyakarta, hlm. 13. 
Penghimpunan dana adalah kegiatan usaha yang dilakukan bank syariah untuk mendapatkan dana dari masyarakat dalam bentuk simpanan atau investasi. Sedangkan penyaluran dana adalah kegiatan usaha yang dilakukan bank syariah dalam bentuk pembiayaan kepada masyarakat yang membutuhkan. Kegiatan penghimpunan dana dan penyaluran dana tersebut dalam dunia perbankan dikenal dengan fungsi financial intermediary. Baik dalam penghimpunan dana maupun dalam penyaluran dana, bank syariah harus selalu berpegang pada prinsip syariah sebagaimana telah ditentukan dalam Al-Qur'an, Hadits Nabi SAW dan Ijtihad ulama. ${ }^{2}$ Kegiatan penghimpunan dana oleh bank syariah dilakukan dalam bentuk simpanan, yaitu dalam bentuk tabungan, giro atau bentuk lain yang dipersamakan dengan itu, dan investasi, yaitu dalam bentuk tabungan, deposito atau bentuk lain yang dipersamakan dengan itu. ${ }^{3}$

Menurut Pasal 1 Angka 21 Undang-Undang Perbankan Syariah, yang dimaksud dengan tabungan adalah simpanan berdasarkan akad wadi'ah atau investasi dana berdasarkan akad mudharabah atau akad lain yang tidak bertentangan dengan prinsip syariah yang penarikannya hanya dapat dilakukan menurut syarat dan ketentuan tertentu yang disepakati, tetapi tidak dapat ditarik dengan cek, bilyet giro, dan/atau alat lainnya yang dipersamakan dengan itu. Sedangkan menurut Fatwa Dewan Syariah Nasional No: 02/DSN-MUI/IV/ 2000 tentang Tabungan, ditentukan bahwa tabungan yang tidak dibenarkan secara syariah, yaitu tabungan yang berdasarkan perhitungan bunga dan tabungan yang dibenarkan, yaitu tabungan yang berdasarkan prinsip Mudharabah dan Wadi'ah.

Sebagaimana ditentukan dalam Fatwa DSN di atas, salah satu prinsip yang digunakan bank syariah dalam melaksanakan kegiatan menghimpun dana yang berbentuk tabungan adalah prinsip mudharabah. Dalam tabungan yang menggunakan akad dengan prinsip mudharabah terdapat dua pihak, yang pertama shahibul maal, yaitu nasabah yang bertindak sebagai penyedia dana dan yang kedua mudharib, yaitu bank yang bertindak sebagai pengelola dana. Fatwa Dewan Syariah Nasional No: 02/DSN-MUI/IV/2000 tentang Tabungan menyebutkan bahwa bank syariah sebagai pengelola dana (mudharib) menutup biaya operasional tabungan dengan menggunakan nisbah keuntungan yang menjadi haknya dan bank tidak diperkenankan mengurangi nisbah keuntungan nasabah penyimpan tabungan mudharabah.

Mudharabah adalah akad kerjasama antara shahibul maal (pemilik modal) dengan mudharib (pengelola dana), di mana shahibul maal memberikan modal kepada mudharib untuk mengelolanya, apabila terdapat keuntungan, maka keuntungan tersebut menjadi milik bersama yang akan dibagi sesuai dengan yang telah disepakati oleh kedua para pihak. ${ }^{4}$ Sementara itu jika terjadi kerugian usaha, maka kerugian tersebut menjadi tanggungjawab pihak shahibul maal.

\footnotetext{
2 https://izzanizza.wordpress.com/2012/03/21/penghimpunan-dana-di-bank-syariah/ diunduh hari ahad 13 mei 2018 pukul 07:24

3 Pandia, F. (2012). Manajemen Dana dan Kesehatan Bank. Jakarta: Rineka Cipta, hlm.7.

4 Zuhaili, W.A. (2011). Fikih Islam. Jilid 5, Depok: Gema Insani, hlm. 476.
} 
Sebagaimana yang telah diuraikan di atas, bahwa akad mudharabah digunakan oleh bank syariah, salah satunya untuk tabungan. Dalam menjalankan kegiatan penghimpunan dana yang berbentuk tabungan dengan akad mudharabah (selanjutnya disebut tabungan mudharabah), ada beberapa bank syariah yang mengenakan biaya administrasi kepada nasabah, yang dalam hal ini berkedudukan sebagai shahibul maal. Biaya administrasi tersebut akan dikenakan setiap bulan yang kisarannya antara bank syariah yang satu dengan bank syariah yang lainnya berbeda-beda. Ada bank syariah yang mengenakan biaya administrasi setiap bulannya sebesar Rp 10.000 (sepuluh ribu rupiah).

Biaya administrasi yang dikenakan bank syariah kepada nasabah tabungan mudharabah pada bank syariah, pada posisi demikian, cenderung berpotensi adanya pihak yang keberatan, walaupun tidak eksplisit. Kondisi- kondisi yang tidak seimbang dalam setiap transaksi syariah semaksimal mungkin dihindari, agar terbebas dari potensi eksploitatif. Biaya administrasi akan digunakan oleh bank syariah untuk biaya operasional dan fee jasa layanan. ${ }^{5}$

Adapun isi klausula pada akad mudharabah antara pihak shahibul maal dan pihak bank syariah sebagai pengelola dana (mudharib) yang tertera yaitu setiap awal bulan bank syariah akan membebankan biaya pemeliharaan rekening tabungan berikut biaya atas fasilitas bagi penabung sesuai dengan ketentuan dan kebijakan pihak bank.

Berdasarkan latar belakang permasalahan di atas, maka perumusan masalah dalam penelitian ini adalah apakah pengenaan biaya administrasi kepada shahibul maal oleh mudharib pada tabungan mudharabah dapat dibenarkan secara fiqih? Adapun tujuan penelitian ini adalah untuk menemukan landasan fiqih yang berkaitan dengan pengenaan biaya administrasi pada tabungan mudharabah.

\section{Metode}

Jenis penelitian ini adalah penelitian yuridis normatif, yaitu penelitian hukum normatif yang dilakukan untuk menghasilkan argumentasi, teori atau konsep baru sebagai preskripsi dalam penyelesaian masalah yang dihadapi. ${ }^{6}$ Penelitian ini akan mengkaji pengenaan biaya administrasi kepada nasabah tabungan selaku shahibul maal oleh bank syariah selaku mudharib pada tabungan mudharabah dengan menggunakan asas hukum atau fiqih yang berlaku dalam akad mudharabah. Pendekatan yang digunakan adalah pendekatan perundangundangan. Yang dimaksud dengan undang-undang di sini adalah semua peraturan yang yang bersifat mengikat, termasuk al-Quran, Hadits Nabi SAW, dan Ijma' Ulama, termasuk di dalamnya Fatwa DSN MUI.

Penelitian ini bersifat doktrinal yaitu hanya mempelajari bahan-bahan hukum yang berupa bahan hukum primer, sekunder dan tersier. Untuk memperkuat

\footnotetext{
${ }^{5}$ Hasil wawancara dengan pegawai bank syariah, pada tanggal 23 Oktober 2018, pukul 11.06 di kantor bank syariah mandiri.

${ }^{6}$ Marzuki, P.M. (2005). Penelitian Hukum. Kencana, hlm. 35.
} 
data dan argumentasi maka peneliti melakukan wawancara kepada narasumber sebagai bahan hukum sekunder untuk menjelaskan bahan hukum primer yang kemudian dianalisis menggunakan metode preskriptif yaitu mencari kesesuaian pengenaan biaya administrasi yang ditanggung oleh pihak shahibul maal atau pihak mudharib dengan ketentuan asas-asas hukum atau fiqih.

Teori preskriptif digunakan untuk panduan dalam melakukan analisis dengan memberikan penilaian terhadap temuan fakta atau peristiwa hukum yang ada sesuai teori atau tidak.7 Berkaitan dengan penelitian tentang pengenaan biaya administrasi kepada nasabah penyimpan tabungan mudharabah apakah pengenaan biaya administasi kepada nasabah dibolehkan secara syariah karena tidak mempunyai dasar hukum yang jelas.

\section{Hasil Penelitian dan Pembahasan}

\subsection{Tabungan Mudharabah}

Menurut Pasal 1 Angka 21 Undang-Undang Perbankan Syariah yang dimaksud dengan tabungan adalah simpanan berdasarkan akad wadi'ah atau investasi dana berdasarkan akad mudharabah atau akad lain yang tidak bertentangan dengan prinsip syariah yang penarikannya hanya dapat dilakukan menurut syarat dan ketentuan tertentu yang disepakati, tetapi tidak dapat ditarik dengan cek, bilyet giro, dan/atau alat lainnya yang dipersamakan dengan itu. Tabungan di bank syariah dapat dibedakan menjadi dua yaitu tabungan yang menggunakan akad wadi'ah dan tabungan yang menggunakan akad mudharabah.

Tabungan mudharabah adalah tabungan yang dijalankan berdasarkan akad mudharabah. Oleh karena itu, tabungan mudharabah harus selalu mengacu pada prinsip-prinsip mudharabah. Secara etimologis, mudharabah berasal dari kata darb. Dalam bahasa arab, kata ini mempunyai banyak arti, antara lain memukul; dharaba ahmad al-kalba, mengalir; dharaba damuhu, berenang; dharaba fi al ma', berjalan; dharaba fi al-ardh dan lain sebagainya. Perubahan-perubahan yang terjadi dalam kata tersebut bergantung pada kata yang mengikutinya dan konteks yang membentuknya. Namun dibalik keluwesan kata ini dapat ditarik benang merah yang dapat merepresentasikan keragaman makna yang ditimbulkan, yaitu bergeraknya sesuatu kepada sesuatu yang lain. ${ }^{8}$

Secara terminologis, mudharabah diungkap secara bermacam-macam oleh para ulama madzhab. Menurut ulama madzhab Hanafi, mudharabah dimaknai sebagai suatu perjanjian untuk berkongsi di dalam keuntungan, dengan modal dari salah satu pihak dan kerja (usaha) dari pihak lain. Sedangkan madzhab Maliki memaknainya sebagai penyerahan uang di muka oleh pemilik modal dalam jumlah uang yang ditentukan kepada seorang yang akan menjalankan usaha dengan uang itu dengan imbalan sebagian dari keuntungannya. ${ }^{9}$

\footnotetext{
${ }^{7}$ Mukti, F. N. D. dan Yulianto, A. (2017). Dualisme Penelitian Hukum Normative dan Empiris. Cet. Ke 4. Yogyakarta: Pustaka Pelajar, hlm. 150.

8 Mujahidin, A. (2016). Hukum Perbankan Syariah. Jakarta: Rajawali Pers, hlm. 68.

${ }^{9}$ Naf'an. (2014). Pembiayaan Musyarakah dan Mudharabah. Yogyakarta: Graha Ilmu, hlm. 113.
} 
Dalam praktik mudharabah antara Khadijah dengan Nabi, saat itu Khadijah mempercayakan barang dagangannya untuk dijual oleh Nabi Muhammad SAW ke luar negeri. Dalam kasus ini Khadijah berperan sebagai pemilik modal (shahibul maal) sedangkan Nabi Muhammad SAW berperan sebagai pelaksana usaha atau mudharib. ${ }^{10}$ Al-Qur'an membolehkan mudharabah ini dengan mendasarkan pada QS. al-Muzammil ayat 20 yang artinya: "dan orang-orang yang berjalan di muka bumi mencari sebagian karunia Allah SWT". Dalam ayat tersebut terdapat kata yadribun yang asal katanya sama dengan mudharabah, yakni mencari pekerjaan atau menjalankan usaha. ${ }^{11}$

Ibnu Abbas ra meriwayatkan bahwa Abbas bin Abdul Muthalib mengatakan. ${ }^{12}$

"Apabila memberikan harta/modal untuk mudharabah, maka dia mensyaratkan pada pengelolanya (mudharib) agar jangan menyeberangi laut, menuruni lembah, dan membeli binatang tunggangan yang memiliki hati yang basah. Jika mudharib melakukan hal-hal tersebut, maka dia harus menanggungnya. Kemudian syarat-syarat tersebut sampai kepada Rasulullah, dan beliau pun membolehkannya. (HR. Thabrani).

Ibnu Majah meriwayatkan dari Shuhaib r.a. bahwa Nabi SAW. Bersabda: ${ }^{13}$ "Ada tiga perkara yang di dalamnya terdapat keberkahan, yaitu menjual dengan tangguh, muqarodhah (mudharabah, dan mencampur gandum dengan tepung untuk di rumah, bukan untuk dijual." (HR. Ibnu Majah no. 2280, kitab at-Tijarah).

Menurut Antonio, mudharabah adalah akad kerja sama usaha antara dua pihak di mana pihak pertama (shahibul maal) menyediakan dana, sedangkan pihak kedua mudharib sebagai pengelola. Keuntungan usaha secara mudharabah dibagi menurut kesepakatan yang dituangkan dalam kontrak, sedangkan apabila rugi ditanggung oleh pemilik modal selama kerugian itu bukan akibat kelalaian si pengelola, seandainya kerugian tersebut diakibatkan karena kecurangan atau kelalaian si pengelola maka, si pengelola harus bertanggungjawab atas kerugian tersebut. ${ }^{14}$

Dalam peraturan perundang-undangan di Indonesia menjelaskan pengertian mudharabah secara terperinci. Pasal 19 Ayat (1) Huruf c Undang-Undang Perbankan Syariah menjelaskan akad mudharabah adalah akad kerjasama antara shahibul maal dengan mudharib, di mana pemilik modal memberikan modal pada mudharib untuk mengelolanya, dan keuntungan menjadi milik bersama sesuai dengan apa yang mereka sepakati. Selanjutnya dalam Peraturan Bank Indonesia PBI No. 10/16/PBI/2008 tentang Pelaksanaan Prinsip Syariah dalam kegiatan penghimpunan dana dan penyaluran dana serta pelayanan jasa bank syariah, menjelaskan bahwa mudharabah adalah akad kerjasama usaha antara dua pihak,

10 Ibid, hlm. 114.

11 Ibid.

12 Zuhaili, W.A. Op. Cit. hlm. 477.

${ }^{13} \mathrm{Ibid}$.

14 Antonio, M.S. (2001), Bank Syariah dari Teori ke Praktik. Jakarta: Gema Insani Press, hlm. 95 
pihak pertama disebut shahibul maal yang menyediakan dana sedangkan pihak kedua, disebut mudharib yang mengelolah dana. Kemudian dalam Fatwa DSN No: 07/DSN-MUI/IV/2000 tentang Pembiayaan Mudharabah dijelaskan bahwa, pengertian mudharabah adalah akad kerjasama suatu usaha antara dua pihak di mana pihak pertama shahibul maal menyediakan seluruh modal, sedang pihak kedua mudharib bertindak selaku pengelola, dan keuntungan usaha di bagi antara mereka sesuai kesepakatan yang dituangkan dalam kontrak.

Jenis-jenis mudharabah, secara umum, mudharabah terbagi menjadi dua jenis: mudharabah muthlaqah dan mudharabah muqayyadah, yaitu. Pertama, mudharabah muthlaqah yang dimaksud dengan mudharabah muthalaqah adalah bentuk kerja sama antara shahibul maal dan mudharib yang cakupannya sangat luas dan tidak dibatasi oleh spesifikasi jenis usaha, waktu, dan daerah bisnis. Dalam pembahasan fiqih ulama salafus saleh seringkali dicontohkan dengan ungkapan if'al ma syi'ta (lakukanlah sesukamu) dari shahibul maal ke mudharib yang memberi kekuasaan sangat besar. ${ }^{15}$ Kedua, mudharabah muqayyadah kebalikan dari mudharabah muthlaqah, ia merupakan restricted mudharabah/specified mudharabah. mudharib atau nasabah dibatasi dengan ketentuan khusus, seperti siapa nasabah dan apa jenis usahanya. ${ }^{16}$

Esensi akad mudharabah adalah kerjasama untuk mencapai keuntungan. Oleh karena itu, keuntungan harus diketahui kadarnya. Apabila keuntungan tidak jelas, maka akibatnya akad mudharabah bisa jadi fasid. Apabila nasabah atau shahibul maal menyerahkan modal kepada mudharib atau pengelola sebesar Rp 10.000.000,00 Setelah modal itu dijalankan oleh pihak bank atau mudharib dan kemudian menghasilkan uang sebesar Rp 12.000.000,00 maka yang dimaksud keuntungan adalah yang Rp 2.000.000,00 karena keuntungan adalah kelebihan dari modal, maka yang dibagi antara shahibul maal dengan mudharib adalah yang Rp 2.000.000,00 tersebut.

Menurut Fatwa Dewan Syariah Nasional DSN-MUI No: 7/DSNMUI/IV/20002000. Syarat keuntungan yang berkaitan dengan mudharabah, disyaratkan sebagai berikut:

a. Harus diperuntukkan bagi kedua pihak dan tidak boleh disyaratkan hanya satu untuk satu pihak.

b. Bagian keuntungan proporsional bagi setiap pihak harus diketahui dan dinyatakan pada waktu kontrak disepakati dan harus dalam bentuk prosentase (nisbah) dari keuntungan sesuai kesepakatan. Perubahan nisbah harus berdasarkan kesepakatan.

c. Penyedia dana menanggung semua kerugian akibat dari mudharabah, dan pengelola tidak menanggung kerugian apa pun kecuali diakibatkan dari kesalahan disengaja, kelalaian, atau pelanggaran kesepakatan.

15 Ibid, hlm. 97

16 Purnamasari, I.D. dan Suswinarno. (2011). Akad Syariah. Bandung: PT Mizan Pustaka, hlm. 90. 
Dengan ketentuan mereka bersekutu dalam keuntungan, maka akad semacam itu hukumnya sah, dan keuntungan nisbah yang telah disepakati sebelumnya oleh para pihak, misalnya 50:50, 60:40 atau 65:35.

Apabila dibuat syarat yang menyebabkan ketidakjelasan dalam keuntungan, maka mudharabah menjadi fasid, karena tujuan akad, yaitu keuntungan tidak tercapai. Akan tetapi, jika syarat tersebut menyebabkan keuntungan menjadi tidak jelas, maka syarat tersebut batal, tetapi akadnya tetap sah. Misalnya, pemilik modal mensyaratkan kerugian ditanggung oleh mudharib atau oleh mereka berdua, maka syarat tersebut batal, tetapi akad mudharabah tetap sah, sedangkan kerugian tetap ditanggung pemilik modal. ${ }^{17}$ Ulama Malikiyah berpendapat bahwa boleh mensyaratkan seluruh keuntungan untuk amil. Boleh mensyaratkan seluruh keuntungan dalam qiradh untuk pemilik modal, amil atau yang lainnya, akan tetapi hal ini termasuk tabarru atau pemberian sukarela. ${ }^{18}$

Syarat keuntungan berdasarkan Fatwa DSN No: 02/DSN-MUI/IV/2000 tentang Tabungan berdasarkan Mudharabah yaitu:

a. Pembagian keuntungan harus dinyatakan dalam bentuk nisbah dan dituangkan dalam akad pembukaan rekening.

b. Bank sebagai mudharib menutup biaya operasional tabungan dengan menggunakan nisbah keuntungan yang menjadi haknya.

c. Nisbah bagi hasil ditentukan di awal

Tabungan mudharabah memang ditujukan untuk memenuhi keinginan nasabah dalam hal ini shahibul maal yang mengharapkan keuntungan atas uang yang disimpan di bank. Besarnya keuntungan yang akan diterima oleh nasabah penabung telah ditentukan dalam nisbah tertentu di awal perjanjian. ${ }^{19}$ Nisbah keuntungan dalam akad mudharabah harus dinyatakan dalam bentuk presentase antara kedua belah pihak, bukan dinyatakan dalam nominal rupiah tertentu. Jadi nisbah keuntungan itu misalnya 50:50, 70:30, atau 60:40. Jadi nisbah keuntungan ditentukan berdasarkan kesepakatan, bukan berdasarkan porsi setoran modal tentu dapat saja bila disepakati nisbah keuntungan sebesar porsi setoran modal. ${ }^{20}$

Faktor-faktor yang mempengaruhi bagi hasil:21

a. Faktor langsung

Salah satu ciri al mudharabah adalah nisbah yang harus ditentukan dan disetujui pada awal perjanjian, nisbah antara satu bank dan bank lainnya dapat berbeda, nisbah juga dapat berbeda dari waktu ke waktu dalam satu bank, misalnya deposito 1 bulan, 3 bulan, 6 bulan, dan nisbah juga dapat

17 Ibid.

18 Zuhaili, W.A., Op. Cit, hlm. 488.

${ }^{19}$ Abdul Ghofur Anshori, (2009), Perbankan Syariah di Indonesia. Yogyakarta: Gadja Mada Universitas Press, hlm. 98.

${ }^{20}$ Farida Purwaningsih. (2016). “Pengaruh Tabungan Mudharabah, Pembiayaan MudharabahMusyarakah Dan Pendapatan Operasional Lainnya Terhadap Laba Studi Pada Bank Jatim Syariah Periode 2007-2015". An-Nisbah, 02(2): 80.

${ }^{21}$ Muhammad Syafii Antonio, (2001), Bank Syariah Dari Teori Ke Praktik. Jakarta: Gema Insani Press, hlm. 139-140. 
berbeda antara satu account dan account lainnya sesuai dengan besarnya dana dan jatuh temponya.

b. Faktor tidak langsung

Penentuan butir-butir pendapatan dan biaya mudharabah. Bank dan nasabah melakukan share dalam pendapatan dan biaya (profit and sharing). Pendapatan yang dibagihasilkan merupakan pendapatan yang diterima dikurangi biaya-biaya.

Fatwa DSN No: 02/DSN-MUI/IV/2000 tentang Tabungan berdasarkan Mudharabah yaitu, bank tidak diperkenankan mengurangi nisbah keuntungan nasabah tanpa persetujuan yang bersangkutan. Dalam akad mudharabah, di mana pihak mudharib menanggung segala operasional dan shahibul maal menanggung risiko, dan keuntungan dibagi bersama sesuai kesepakatan. Sehingga pihak mudharib dalam hal ini bank hanya berhak atas nisbahnya, mudharib tidak diperkenankan mengurangi keuntungan pihak shahibul maal, apalagi sampai mengambil modal pokok untuk digunakan bank untuk membiayai operasional bank.

Mudharib berhak mendapatkan keuntungan yang telah disepakati sebagai kompensasi atas pekerjaannya dalam mudharabah jika dalam mudharabah itu mendapatkan keuntungan. Jika tidak ada keuntungan, maka mudharib tidak berhak mendapatkan apa pun, karena dia telah bekerja untuk dirinya sendiri sehingga tidak berhak mendapatkan upah. Keuntungan itu bisa diketahui setelah adanya pembagian, dan syarat bolehnya dilakukan pembagian adalah diterimanya kembali modal mudharabah. Maka tidak sah pembagian keuntungan sebelum modal diambil dari tangan mudharib. Ulama Hanafiyah berpendapat sama dengan ulama Malikiyah dan Syafiiyah dalam pendapat yang azhhar bahwa amil tidak memiliki bagian keuntungan dari pekerjaannya kecuali dengan sebab adanya keuntungan. Zaidiyah berpendapat bahwa amil memiliki bagian dari keuntungan sebelum dibagi. Para Fuqaha sepakat bahwa amil wajib menyerahkan modal mudharabah. Amil tidak memiliki hak apa pun dari keuntungan sampai menyerahkan modal mudharabah pada pemilik modal. Keuntungan mudharabah adalah jumlah yang melebihi jumlah modal. Keuntungan tersebut dibagi antara amil dan pemilik modal sesuai dengan kesepakatan. ${ }^{22}$

\subsection{Biaya Administrasi}

Biaya adalah suatu permintaan akan data biaya yang harus disertai dengan penjelasan mengenai tujuan dan keperluan penggunaannya, karena data biaya yang sama belum tentu dapat memenuhi tujuan dan keperluan yang ada. ${ }^{23}$ Administrasi adalah serangkaian kegiatan yang dilakukan untuk mencapai tujuan tertentu. ${ }^{24}$ Secara umum pengertian biaya administrasi adalah biaya yang

22 Zuhaili, W.A. (2011). Fikih Islam. Jilid 5. Depok: Gema Insani, hlm. 506-507

23 Kartadinata, A. (1986). Akuntansi dan Analisis Biaya. Jakarta: Bina Aksara, hlm. 24

24Bisri, S. (2015). Pengaruh Produk Pembiayaan Kredit Pemilikan Rumah (KPR) dan Biaya Administrasi

Terhadap Kepuasan Nasabah di Bank Muamalat Indonesia Cabang Pembantu Tulungagung.

Tulungagung, hlm. 53 
dikeluarkan oleh suatu perusahaan untuk keperluan operasional perusahaan tersebut. Secara umum, biaya administrasi yang ada pada bank akan dikenakan kepada nasabah tabungan yang besarannya tergantung pada kebijakan masingmasing bank.

Tujuan atau pemanfaatan biaya administrasi, yaitu untuk keperluan operasional bank seperti biaya operasional termasuk membiayai SDM dan Fee jasa layanan serta produk-produk perbankan lainnya yang merupakan kegiatan penunjang untuk melancarkan bank dalam menjalankan fungsi utamanya, yaitu kegiatan menghimpun dan menyalurkan dana. Dengan semakin lengkap fasilitas dan semakin baik layanan bank akan dapat banyak memberikan keuntungan bagi bank, karena akan semakin menarik banyak orang untuk menjadi nasabah bank tersebut. ${ }^{25}$

\subsection{Pengenaan Biaya Administrasi pada Nasabah Penyimpan Tabungan Mudharabah}

Dalam konstruksi hukum tabungan mudharabah modal merupakan milik shahibul maal, usaha merupakan milik mudharib, dan keuntungan merupakan milik bersama antara shahibul maal dan mudharib. Dengan demikian maka risiko berkurangnya modal menjadi tanggung jawab shahibul maal, biaya untuk operasional usaha menjadi tanggung jawab pengelola dana atau mudharib dan keuntungan menjadi hak kedua belah pihak, yaitu shahibul maal dan mudharib, oleh karena itu keuntungan nantinya harus dibagi dua.

Dalam praktik perbankan syariah ada beberapa bank syariah yang mengenakan biaya administrasi, di mana biaya administrasi tersebut nantinya akan digunakan untuk membiayai operasional bank syariah. Jadi pada dasarnya biaya administrasi adalah biaya operasional. Bank syariah yang mengenakan biaya administrasi pada tabungan mudharabah, biasanya akan mengambil dari rekening nasabah tabungan mudharabah (shahibul maal) secara auto debit setiap bulannya yang besarannya berbeda-beda antara bank syariah yang satu dengan bank syariah yang lain.

Tentu saja, biaya administrasi tersebut akan mengurangi keuntungan yang menjadi hak nasabah tabungan mudharabah (shahibul maal), apabila keuntungan yang diterima oleh nasabah tabungan mudharabah (shahibul maal) besar. Tetapi apabila keuntungan yang menjadi bagian nasabah tabungan mudharabah kecil, maka akan dapat mengurangi modal dari nasabah tabungan mudharabah (shahibul maal). Hal ini menjadikan hanya bank syariah (mudharib) saja yang menikmati keuntungan mudharabah, sementara nasabah tabungan mudharabah (shahibul maal) tidak menikmati keuntungan sama sekali. ${ }^{26}$ Misalnya, biaya administrasi yang dipungut oleh pihak bank syariah sebesar Rp 10.000,00, apabila nasabah tabungan mudharabah (shahibul maal) pada bulan Februari 2019 mendapatkan pembagian keuntungan sebesar $\mathrm{Rp} 25.000,00$, kemudian nasabah tabungan

\footnotetext{
25Sandy, M. http://www.akuntansilengkap.com/akuntansi/20-contoh-jasa-layanan-bankm produk-perbankan-lengkap/ diunduh Senin, 05 November 2018 pukul 23.00.
}

${ }^{26}$ Muslich, A.W. (2010). Figh Muamalat. Jakarta: Amzah, hlm. 383. 
mudharabah (shahibul maal) dikenakan biaya administrasi sebesar Rp 10.000,00, maka keuntungan yang diterima nasabah tabungan mudharabah (shahibul maal) tersebut menjadi hanya $\mathrm{Rp} 15.000,00$. Selanjutnya, apabila pembagian keuntungan yang diterima oleh nasabah tabungan mudharabah (shahibul maal) pada bulan Maret 2019 hanya Rp 3.500,00, dan kemudian dikenakan biaya administrasi sebesar Rp 10.000, maka pada bulan tersebut nasabah tabungan mudharabah (shahibul maal) pada dasarnya tidak menerima pembagian keuntungan, karena nilai pembagian keuntungan lebih kecil dibandingkan biaya administrasi, bahkan modal pokok nasabah tabungan mudharabah (shahibul maal) akan berkurang sebesar Rp 6.500,00 untuk menutup kekurangan biaya administrasi.

Kenyataan di atas dirasakan tidak adil bagi pihak nasabah tabungan mudharabah (shahibul maal), karena keuntungan dari pengelolaan modal mudharabah hanya dinikmati oleh bank syariah selaku mudharib. Sementara, pihak nasabah tabungan mudharabah (shahibul maal) sebagai pemilik modal, tidak menikmati keuntungan atas pengelolaan dana mudharabah tersebut.

Dalam ketentuan fiqih tentang mudharabah, memang ada beberapa fuqaha yang membolehkan mudharib mengambil biaya pengelolaan. Fuqaha yang membolehkan mudharib mengambil biaya operasional adalah Ibrahim an-Nakhai dan Hasan al-Bashri, Abu Hanifah, Malik, Syi'ah Zaidiyah, ulama Hanafiah dan ulama Hanabilah.

Ibrahim An-Nakhai dan Hasan Bashri berpendapat bahwa mudharib berhak atas biaya operasional baik pada saat menetap maupun pada saat bepergian. Abu Hanifah, Imam Malik, dan Syi' ah Zaidiyah mengatakan bahwa mudharib dapat mengambil biaya operasional hanya pada saat dia pergi. Sedangkan apabila dia menetap, maka mudharib tidak berhak atas biaya operasional. Biaya tersebut diambilkan dari keuntungan, apabila usaha mudharabah menghasilkan keuntungan, dan diambilkan dari modal apabila tidak ada keuntungan. Yang dimaksud dengan biaya operasional di sini meliputi apa yang dibutuhkan mudharib, seperti makan dan pakaian. Berkaitan dengan sumber dana biaya operasional Imam Malik berbeda pendapat, yaitu mudharib dapat mengambil biaya operasional hanya jika modal dapat mencukupi untuk itu. Apabila modal tidak mencukupi, maka mudharib tidak berhak atas biaya operasional, kecuali usaha mudharabah menyibukkannya sehingga tidak dapat mencari pekerjaan lain untuk makan. ${ }^{27}$

Ulama Hanabilah berpendapat bahwa mudharib dapat mengambil biaya operasional untuk dirinya, baik pada waktu menetap maupun pada waktu bepergian. Ulama Hanafiah juga membolehkan bahkan wajib untuk memberikan biaya operasional kepada mudharib, yang berupa makan, minum, pakaian, bahkan tenaga kerja. ${ }^{28}$

\footnotetext{
${ }^{27}$ Zuhaili, W.A. (2011). Op. Cit., hlm. 503.

${ }^{28}$ Ibid., hlm. 503
} 
Sementara Imam Syafii berpendapat bahwa mudharib tidak berhak mengambil modal mudharabah untuk biaya operasional baik pada waktu menetap maupun pada saat bepergian, kecuali jika shahibul maal mengijinkannya. ${ }^{29}$

Di Indonesia, dalam praktik perbankan syariah, dengan mendasarkan pada Fatwa Dewan Syariah Nasional Majelis Ulama Indonesia Nomor: 02/DSNMUI/IV/2000, bank syariah sebagai mudharib menutup biaya operasional tabungan mudharabah dengan menggunakan nisbah keuntungan yang menjadi haknya. Bank syariah sebagai mudharib tidak diperkenankan mengurangi nisbah keuntungan nasabah tanpa persetujuan yang bersangkutan.

Fatwa Dewan Syariah Nasional Majelis Ulama Indonesia di atas mendasarkan pada ketentuan yang ada dalam Al-Quran dan Hadits Nabi SAW., salah satunya adalah QS. An-Nisa ayat 29, yang artinya: "Hai orang yang beriman! Janganlah kalian saling memakan (mengambil) harta sesamamu dengan jalan yang batil, kecuali dengan jalan perniagaan yang berlaku dengan sukarela di antaramu...".

Mendasarkan pada ketentuan QS. An-Nisa ayat 29 tersebut tampaknya Dewan Syariah Nasional Majelis Ulama Indonesia ingin lebih mengedepankan prinsip keadilan. Kita dilarang mengambil harta orang lain dengan cara yang batil, karena hal itu akan merugikan orang tersebut. Perbuatan seperti itu akan menciptakan ketidakadilan.

Di samping itu, akad mudharabah adalah salah satu akad yang bersifat amanah. Mudharib adalah orang yang mendapat amanah dari shahibul maal untuk menjalankan atau mengusahakan harta mudharabah dalam rangka untuk mencari keuntungan. Sebagai pemegang amanah, maka mudharib tidak bertanggung jawab atas harta mudharabah, kecuali atas kesalahan yang dilakukan dengan sengaja oleh mudharib. ${ }^{30}$ Oleh karena itu, Dewan Syariah Nasional Majelis Ulama Indonesia, juga menjadikan ketentuan-ketentuan amanah menjadi rujukan dalam menetapkan fatwanya tersebut. Salah satunya adalah QS. Al-Baqarah ayat 283, yang artinya: “...Maka, jika sebagian kamu mempercayai sebagian yang lain, hendaklah yang dipercayai itu menunaikan amanatnya dan hendaklah ia bertakwa kepada Allah Tuhannya...".

Dalam praktik perbankan syariah di Indonesia, ketentuan yang ditetapkan oleh Dewan Syariah Nasional Majelis Ulama Indonesia adalah yang telah disepakati untuk dijadikan rujukan. Hal ini mendasarkan pada ketentuan Pasal 26 UndangUndang Perbankan Syariah yang berbunyi:

Pasal 26

\footnotetext{
${ }^{29}$ Ibid., hlm. 503

${ }^{30}$ Sayyid Sabiq, (1993), Fiqih Sunnah, Jilid 13, Bandung:Al-Ma'arif, hlm. 39.
} 
(1) Kegiatan usaha sebagaimana dimaksud dalam Pasal 19, Pasal 20, dan Pasal 21 dan/atau produk dan jasa syariah, wajib tunduk kepada Prinsip Syariah.

(2) Prinsip Syariah sebagaimana dimaksud pada ayat (1) difatwakan oleh Majelis Ulama Indonesia.

Berdasarkan uraian di atas, maka pada prinsipnya bank syariah sebagai mudharib tidak dapat mengenakan biaya administrasi kepada nasabah tabungan mudharabah yang dalam hal ini berkedudukan sebagai shahibul maal. Karena, pengenaan biaya administrasi tersebut akan berakibat mengurangi nisbah keuntungan yang menjadi haknya nasabah tabungan mudharabah (shahibul maal). Pengenaan biaya administrasi yang berarti mengurangi keuntungan yang menjadi hak nasabah tabungan mudharabah (shahibul maal) hanya dapat dilakukan apabila sudah diperjanjikan sebelumnya. Hal ini berarti, biaya administrasi tidak boleh diambil dari modal mudharabah.

Apabila mendasarkan pada pendapat mayoritas fuqaha, pengenaan biaya administrasi dengan cara mengambil dari modal mudharabah baru boleh dilakukan apabila mudharib melakukan perjalanan pada saat menjalankan usaha mudharabah. Padahal kenyataannya, bank syariah selaku mudharib dalam menjalankan kegiatan usaha mudharabah tidak melakukan perjalanan. Oleh karena itu, bank syariah selaku mudharib tidak diperkenankan mengambil biaya administrasi dari modal mudharabah. Sehingga dengan demikian, apabila bagian keuntungan nasabah tabungan mudharabah (shahibul maal) hanya sebesar Rp 3.500,00, maka biaya administrasi yang dapat dikenakan kepada nasabah tabungan mudharabah (shahibul maal) tersebut maksimal hanya Rp 3.500,00 tidak boleh lebih. Itu pun dipersyaratkan diperjanjikan terlebih dahulu antara bank syariah sebagai mudharib dengan nasabah tabungan mudharabah sebagai shahibul maal.

\section{Simpulan}

Pengenaan biaya administrasi kepada nasabah tabungan mudharabah sebagai shahibul maal oleh bank syariah selaku mudharib pada tabungan mudharabah berdasarkan Fatwa Dewan Syariah Nasional Majelis Ulama Indonesia pada prinsipnya tidak diperbolehkan, karena hal itu akan mengurangi nisbah keuntungan yang menjadi hak dari nasabah tabungan mudharabah, sehingga akan menimbulkan ketidakadilan bagi nasabah tabungan mudharabah sebagai shahibul maal. Biaya administrasi yang pada dasarnya merupakan biaya operasional karena akan digunakan untuk menjalankan kegiatan perbankan, menjadi tanggung jawab bank syariah selaku mudharib. Akan tetapi apabila diperjanjikan di awal, pengenaan biaya administrasi kepada nasabah tabungan mudharabah (shahibul maal) diperbolehkan, tetapi hanya dapat diambilkan dari keuntungan yang menjadi bagian nasabah tabungan mudharabah. Pengenaan biaya administrasi tidak boleh mengambil dari modal mudharabah, karena modal mudharabah pada dasarnya mutlak milik nasabah tabungan mudharabah (shahibul maal). 


\section{Daftar Pustaka}

\section{Buku:}

Anshori, A.G. (2009). Perbankan Syariah di Indonesia, cetakan ke dua, Yogyakarta: Gadja Mada University Press.

Antonio, M.S. (2001). Bank Syariah dari Teori ke Praktik, Jakarta: Gema Insani Press.

Anwar, S. (2007). Hukum Perjanjian Syariah: Study Tentang Akad dalam Fiqih Muamalat, Jakarta: RajaGrafindo Persada.

Bisri, S. (2015). Pengaruh Produk Pembiayaan Kredit Pemilikan Rumah (KPR) dan Biaya Administrasi terhadap Kepuasan Nasabah di Bank Muamalat Indonesia Cabang Pembantu Tulungagung, Tulungagung:

Dewata, MNF. dan Ahmad Y. (2017). Dualisme Penelitian Hukum Normatif dan Empiris, cet ke-4, Yogyakarta: Pustaka Pelajar.

Kartadinata, A. (1986). Akuntansi dan Analisi Biaya, Jakarta: Bina Aksara.

Marzuki, P.M. (2005). Penelitian Hukum, Jakarta: Kencana.

Muhammad, (2005). Konstruksi Mudharabah dalam Bisnis Syariah, Yogyakarta: BPFE-Yogyakarta.

Mujahidin, A. (2016). Hukum Perbankan Syariah, Jakarta: Rajawali Pers.

Muslih, A.W. (2010). Fiqih Muamalat, Jakarta: Amzah.

Naf'an. (2014). Pembiayaan Musyarakah dan Mudharabah, Yogyakarta: Graha Ilmu.

Pandia, F. (2012). Manajemen Dana dan Kesehatan Bank, Jakarta: Rineka

Purnamasari, I.D. dan Suswinarno. (2011). Akad Syariah, Bandung: PT Mizan Pustaka.

Purwaningsih, F. (2016). Pengaruh Tabungan Mudharabah, Pembiayaan MudharabahMusyarakah dan Pendapatan Operasional Lainnya terhadap Laba Studi pada Bank Jatim Syariah Periode 2007-2015, An-Nisbah, 02(02).

Sabiq, S. (1993). Fiqih Sunnah. Jilid 13, Bandung: Al-Ma'arif.

Zuhaili, W.A. (2011). Fiqih Islam. Jilid 5, Depok: Gema Insani.

\section{Artikel Jurnal:}


Fajri, I. (2015). Pembebanan Biaya Administrasi dalam Praktik Perbankan Syariah Ditinjau dari Aspek Teori Keadilan dan Hukum Perbankan Syariah, Jurnal Yustisi, 2 (2).

\section{Web:}

Sandy Makruf. http://www.akuntansilengkap.com/akuntansi/20-contoh-jasalayanan-bank-produk-perbankan-lengkap/ diunduh Senin, 05 November 2018 pukul 23.00.

https:/ /izzanizza.wordpress.com/2012/03/21/penghimpunan-dana-di-banksyariah/diunduh hari Ahad 13 Mei 2018 pukul 07:24

\section{Peraturan Perundang- undangan:}

Undang-Undang Republik Indonesia Nomor 21 Tahun 2008 tentang Perbankan Syariah.

Fatwa DSN No: 02/DSN-MUI/IV/2000 tentang Tabungan.

Fatwa DSN No: 07/DSN-MUI/IV/2000 tentang Pembiayaan Mudharabah. 